may be expected. Of this total a large percentage has to be extracted in order to adapt the underground atmospheric conditions to the health and physical efficiency of the workers.

Three methods in operation were described. At the Robinson Deep Mine, a surface refrigeration plant is used which deals with 407,000 cubic feet of air per minute, cooling it from $65^{\circ} / 60^{\circ} \mathrm{F}$. wet bulb temperature to $38^{\circ} / 33^{\circ} \mathbf{F}$., the cooled air being sent down the downcast shaft to a depth of 7,500 feet. Underground refrigeration is adopted at the East Rand Proprietary Mine and the plant treats more than 8,000 tons of air per day, cooling it from $81^{\circ}$ to $72^{\circ}$. As a contrast to these systems, dehumidified compressed air is used at various mines of the AngloAmerican Corporation by employing it at every possible machine underground. This eliminates one source of heat in the use of electric motors, and from the practical point of view offers a much simpler system at the hot spots than any of the others. Devaporization of the air is effected by overcompression. It is first compressed to $90 \mathrm{lb}$./in. ${ }^{2}$ abs. and then taken to an over-compressor where it is raised to $130 \mathrm{lb} . /$ in. $^{2}$ abs. It next passes through a cooler, the first water separator, the heat exchanger where it is further cooled, and a second water separator from which it goes to the expansion turbine. Then after passing through a third water separator and the heat exchanger it goes to the compressed air pipes in the downcast shaft.

As the wet method of mining is responsible for a substantial portion of the problem presented, the authors also discussed the relative advantages which would accrue from the adoption of drier methods and dealt with the concomitant problem of the prevention of dust.

\title{
Preservation of Antiquities of South Africa
}

$\mathrm{W}$ ITH the view of safeguarding the evidence of antiquity in South Africa, the Minister of the Interior of the Union of South Africa has published orders prohibiting the removal or export of monuments, relics, or antiques without the written consent of the Commission for the Preservation of the Natural and Historical Monuments, Relics and Antiques (Notices No. 1571 and No. 1572, Gazette of the Government of the Union of South Africa, Sept. 20, 1938, No. 2569 , pp. 955-958). The orders are made under the provisions of Section 10 of the Natural and Historical Monuments, Reliques and Antiques Act, 1934, as amended by Section 4 of the Natural Monuments Amendment Act, 1937. The antiquities covered are specifically stated to be drawings, paintings, and petroglyphs of the Bushmen, or other aboriginals, or peoples inhabiting South Africa prior to the arrival of the Europeans, implements or ornaments known or commonly believed to have been used by them, and any anthropological or archæological contents of the graves, caves, rock shelters, middens or shell mounds, and any vertebrate fossil. Further, the orders cover any objects that have been proclaimed, or are capable of proclamation, as antique.

While the Commission thus entrusted with the responsibility of deciding to whom permits shall be accorded under the orders, is most anxious to encourage the exploration of the rich archæological and palæontological fields of the Union of South Africa, and welcomes research by all who are properly equipped, it is determined to do everything in its power to ensure proper investigation and to put an end to such reckless exploitation-often unwittingas has been all too common in the part. With this object the orders now published embody by-laws which lay down regulations upon which the consent of the Commission to the excavation or removal of relics is made dependent.

These regulations preseribe the terms of the application, which must define the character of the antiquities and their exact location with a locality sketch of the area, and require that after removal the Commission shall be furnished with a description of the objects removed, a statement of their destin- ation, and when the investigation is archæological, a complete set of plans and stratigraphical records. Further, the excavator may not dispose of any object without the written consent of the Commission by whom is also reserved the right to retain in South Africa a representative collection of the excavator's finds. While the right of scientific ownership is recognized, this may lapse if suitable publication does not follow within such time as the Commission may approve.

In order to ensure the proper character and tech. nique of the excavation, not only must the application to investigate set out the applicant's credentials, but also access to the excavation is reserved to the Commission or its representatives; uncivilized labour must be properly supervised, all material must be sieved through a prescribed size of mesh, and photographs of material in situ, and of sections of stratified deposits must be submitted with notes to the Commission as soon as possible. Finally, not only must a witness section be left intact, but also not more than one half of any known area of a site shall be demolished, removed or excavated without the specific authority of the Commission.

The regulations, though drastic, are such as no archæologist could fail to approve. It is eminently reasonable that the South African authorities should seek to protect their antiquities from the fate by which other countries too often have suffered, owing to the removal from its place of origin of evidence of value, sometimes unique, of past cultural achievement. Even more important is it, especially in a country so sparsely populated and so difficult for supervision, as South Africa, to secure that antiquities are not wantonly despoiled, either through ignorance or through the indiscriminate greed of the curio hunter, but that when they must be made the subject of investigation in the interests of science, their evidence should be made available for the advancement of learming by examination under supervision in accordance with an approved scientific technique and by fully qualified and responsible investigators. The provision that part of any excavated site, unless otherwise determined, must be left undisturbed, is especially commendable. 